\title{
PENANAMAN NILAI-NILAI KARAKTER RELIGIUS DAN DISIPLIN MELALUI PROGRAM TAUSIYAH AKHLAK DI SMP AL-FURQAN JEMBER
}

\author{
Lutfia Septiyani \\ Institut Agama Islam Negeri Jember \\ Email: lutfia.aza27@gmail.com \\ Bambang Irawan \\ Institut Agama Islam Negeri Jember \\ Email: bambangirawan1976@gmail.com
}

DOI: $10.35719 /$ adabiyah.v2i1.74

\begin{abstract}
Abstrak
Penelitian ini bertujuan untuk mendeskripsikan bagaimana cara penanaman nilai karakter religius dan disiplin di sekolah melalui program tausiyah akhlak maka seharusnya menghasilkan pembentukan karakter religius siswa yaitu menanamkan keimanan siswa, menambah wawasan keagamaan siswa, dan melaksanakan segala sesuatunya dengan penuh tanggung jawab dan tepat waktu. Penelitian ini menggunakan pendekatan kualitatif deskriptif. Lokasi penelitian ini berada di SMP Al-Furqan Jember. Hasil penelitian ini menunjukkan bahwa cara menanamkan nilai karakter religius dan disiplin salah satunya melalui program tausiyah akhlak, program ini merupakan pembinaan siswa yang dipimpin oleh pemateri dari luar dan guru, dilaksanakan setiap hari Jumat setelah sholat dhuha dan materi yang disampaikan seputar akhlak. Program tersebut diimbangi dengan pembiasaan yang dilaksanakan di sekolah, karena sebagai praktek siswa. Contohnya, sebelum masuk sekolah shalat dhuha berjamaah, kegiatan kultum dan sebagainya. Oleh karena itu, tujuan membentuk karakter religius dan disiplin adalah membentuk siswa yang beriman dan melaksanakan segala sesuatunya dengan penuh tanggung jawab dan disiplin, salah satunya dengan cara mengikuti pembinaan program tausiyah akhlak.
\end{abstract}

Kata Kunci: karakter religius, karakter disiplin, program tausiyah akhlak

\begin{abstract}
This study aims to describe how to instill the values of religious character and discipline in schools through the tausiyah akhlak program, so it should result in the formation of students 'religious character, namely instilling student faith, increasing students' religious insight, and carrying out everything responsibly and on time. This research uses a descriptive qualitative approach. The location of this research is at SMP Al-Furqan Jember. The results of this study indicate that the way to instill the values of religious character and discipline is one of them through the tausiyah akhlak program, this program is a student coaching led by external speakers and teachers, carried out every Friday after the dhuha prayer and the material conveyed
\end{abstract}




\section{AL-ADABIYAH: Jurnal Pendidikan Agama Islam}

is about morals. The program is balanced with habituation carried out in schools, because it is a student practice. For example, before entering the dhuha prayer school in congregation, cult activities and so on. Therefore, the aim of forming religious and disciplined characters is to form students who believe and carry out everything with full responsibility and discipline, one of which is by following the tausiyah akhlak development program.

Keyword: religious character, discipline character, tausiyah akhlak program

\section{Pendahuluan}

Penanaman karakter sejak dini menjadi sangat penting karena akan mengantarkan anak dengan potensi yang dimilikinya sehingga menjadi insan beradab dengan tetap berpegang teguh pada nilai-nilai kemanusiaan dan kekhalifaan. Menurut ajaran agama Islam, akhlak atau karakter memiliki posisi penting karena setiap umat yang memperbaiki akhlaknya akan ditinggikan derajatnya oleh Allah SWT sekaligus akan menjadi orang yang bahagia hidupnya. Hal ini sesuai dengan tujuan pendidikan nasional yang termaktub dalam UndangUndang Nomor 20 Tahun 2003 pada Bab II Pasal 3, yaitu pendidikan nasional berfungsi untuk mengembangkan kemampuan dan membentuk watak serta peradaban bangsa yang bermartabat dalam rangka mencerdaskan kehidupan bangsa untuk mengembangkan potensi peserta didik agar menjadi manusia yang beriman dan bertakwa kepada Tuhan Yang Maha Esa, berakhlak mulia, sehat, berilmu, cakap, kreatif, mandiri dan menjadi warga negara yang demokratis serta bertanggung jawab.

Pada masa teknologi yang terus berkembang dan semakin canggih. Banyak permasalahan yang sering terjadi setiap harinya, hal ini bisa diakses melalui gadget, televisi maupun elektronik lainnya. Permasalahan yang terjadi salah satunya mengenai dunia pendidikan, karena semakin hari krisis karakter diindonesia melahirkan keprihatinan, contohnya pergaulan bebas, mencontek, dan tawuran. Hal ini mejadikan budaya di indonesia, karena tidak ada penanggulan yang ketat untuk permasalahan tersebut. Generasi muda tidak bisa menjawab tantangan dunia, padahal setiap harinya telah dilakukan perbaikan dengan tujuan untuk menjadikan bangsa Indonesia memiliki kualitas yang baik.

Memperbaiki karakter perlu adanya dorongan internal yang berasal dari keluarga dan dorongan eksternal yang berasal dari lingkungan masyarakat maupun sekolah. Sekolah sebagai penentu bagi perkembangan siswa baik cara berpikir, bersikap maupun berperilaku. Membentuk karakter siswa tidak lepas dari 


\section{AL-ADABIYAH: Jurnal Pendidikan Agama Islam}

peran seorang guru, karena setiap perilaku dan sikap seorang guru akan menjadi teladan bagi siswa.

Berbagai macam kegiatan telah diciptakan oleh sekolah untuk menanamkan nilai karakter siswa yang bertujuan untuk menciptakan dan menguatkan karakter individu sesuai dengan moral dan ajaran agama islam, bentuk-bentuk kegiatan tersebut salah satunya yaitu program tausiyah akhlak. Terbentuknya program tausiyah akhlak karena didalam diri siswa telah memiliki nilai karakter dan tugas guru adalah mengarahkan siswa untuk memiliki akhlak mulia sesuai dengan ajaran agama islam. Setelah siswa mengikuti program tausiyah akhlak, siswa dapat mempraktekkan dalam kehidupan sehari-hari. Program ini dilaksanakan setiap hari jum'at dan sebelum shalat dhuha berjamaah. Program ini berupa pembinaan tausiyah yang disampaikan oleh guru dan setiap bulannya mengundanya pemateri dari luar. Materi yang disampaikan berkaitan dengan akhlak dan biasanya pihak sekolah meminta tema sesuai dengan kondisi yang ada.

Menanamkan karakter siswa melalui tausiyah dipandang sebagai proses pendidikan yang baik dan benar-benar mengacu pada nilai-nilai islam, apabila kegiatan tausiyah telah menjadi pembiasaan bagi siswa akan membentuk komitmen kuat dan siswa mampu memecahkan segala permasalahan yang dihadapi nantinya. Tausiyah merupakan hal kecil yang sering diremehkan masyarakat, tetapi memiliki dampak besar untuk pembangunan bangsa kedepannya. Sekolah membentuk program tersebut bertujuan untuk menanamkan karakter religius dalam hal untuk menanamkan keimanan siswa dan karakter disiplin dalam hal untuk melaksanakan segala sesuatu dengan tepat waktu dan penuh tanggung jawab.

Tujuan artikel penelitian ini adalah untuk mendeskripsikan mengenai penanaman nilai karakter religius dan disiplin melalui program tausiyah akhlak pada siswa kelas VII sedangkan artikel ini terfokus kepada bagaimana cara menanamkan karakter religius dan disiplin melalui program tausiyah akhlak pada siswa kelas VII. Penelitian ini dilakukan dengan mengharap dapat memberikan wawasan keilmuan terkait pembentukan karakter dan memberikan motivasi.

\section{Metode}

Penelitian ini menggunakan pendekatan penelitian kualitatif deskriptif karena untuk menggambarkan, atau memaparkan keadaan objek yang diteliti 


\section{AL-ADABIYAH: Jurnal Pendidikan Agama Islam}

sesuai dengan situasi dan kondisi ketika penelitian dilakukan. Jenis penelitian yang digunakan adalah studi kasus (Ibrahim, 2015, 55-56). Penelitian ini digunakan untuk mengumpulkan informasi mengenai bagaimana program tausiyah akhlak berjalan sehingga dapat menanamkan karakter religius dan disiplin dalam diri siswa, penelitian ini menggunakan teknik pengumpulan data adalah observasi non partisipatif, untuk mengetahui proses kegiatan program tausiyah akhlak pada siswa kelas VII di SMP Al-Furqan Jember, wawancara semiterstruktur digunakan untuk menggali data dari informan mengenai penanaman nilai karakter religius dan disiplin pada siswa kelas VII di SMP A1Furqan Jember dan data dokumentasi berupa data yang terkait program tausiyah akhlak tersebut.

\section{Tinjauan Literatur}

\section{a. Dasar Penanaman Nilai-Nilai Karakter}

Dasar pembentukan karakter manusia didasari oleh dua potensi yakni menjadi makhluk yang beriman atau ingkar terhadap Tuhannya. Sebagaimana firman Allah berikut ini.

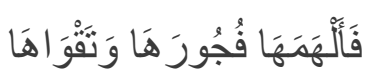

Artinya: Maka Allah mengilhamkan kepada jiwa itu (jalan) kefasikan dan ketakwaannya. (Qs. Al-Syams: 8)

Berdasarkan ayat diatas bahwa setiap manusia memiliki potensi untuk menjadi hamba yang baik (positif) atau buruk (negatif) (Fitri, 2014, 35-36), menjalankan perintah Tuhan atau melanggar larangan-Nya. Setiap manusia memiliki dua potensi yaitu potensi menjadi baik yang digerakkan oleh hati yang baik (qalbu salim), jiwa yang tenang (nasful mutmainnah), akal sehat (aqlus salim), dan pribadi yang sehat (jismus salim) sedangkan potensi menjadi buruk digerakkan oleh hati yang sakit (qalbun maridh), nafsu pemarah (amarah), lacur (lawwamah), rakus (saba'iyah) dan pikiran yang kotor (aqlussu't).

Kaitannya dengan nilai-nilai karakter, Kemendiknas mengidentifikasi butir-butir nilai yang dikelompokkan menjadi lima nilai utama yaitu

a) Nilai karakter berhubungan dengan Tuhan adalah nilai religius yaitu pikiran, perkataan, dan tindakan sesuai dengan nilai ketuhanan dan ajaran agamanya. Dalam islam karakter adalah perilaku dan akhlak yang diajarkan 
dalam pendidikan agama islam sehingga bisa dikatakan karakter religius adalah watak, tabiat atau kepribadian seseorang yang terbentuk dari penanaman berbagai kebijakan yang berlandaskan ajaran agama islam.

b) Nilai karakter dalam berhubungan dengan diri sendiri salah satunya nilai kedisiplinan yaitu suatu pedoman atau pijakan dan landasan dalam berbuat, karena disiplin adalah kunci kesuksesan seseorang. Fungsi utama disiplin adalah mengajarkan siswa untuk mengendalikan diri dengan mudah, menghormati dan mematuhi otoritas sedangkan tujuan disiplin adalah mengupayakan pengembangan minat dan mengembangkan anak menjadi manusia yang baik, menciptakan suasana aman, nyaman, dan menyenangkan bagi kehidupan bermasyarakat dan bernegara sehingga peraturan yang ditetapkan akan ditaati.

c) Nilai karakter hubungannya dengan sesama, meliputi sadar, patuh, menghargai karya dan prestasi orang lain, santun, demokratis.

d) Nilai karakter hubungannya dengan lingkungan, meliputi nilai peduli lingkungan sosial dan lingkungan.

e) Nilai kebangsaan yang berhubungan dengan rasa cinta nasionalisme, meliputi nasionalis dan menghargai keberagaman.

\section{b. Metode Penanaman Karakter}

Menanamkan (internalisasi) karakter bertujuan meningkatkan mutu penyelenggaraan dan hasil pendidikan di sekolah yang mengarah pada pencapaian pembentukan karakter dan akhlak mulia siswa secara utuh, terpadu dan seimbang. Maka perlu adanya metode untuk menanamkan karakter tersebut, Pusat Kurikulum Kementerian Pendidikan Nasional (samani, 2011, 145-146) menyarankan empat metode yang digunakan meliputi:

a) Pembiasaan

Kegiatan yang diamalkan secara terus-menerus dan berulang ulang agar menjadi kebiasaan dan terbentuk karakter yang diinginkan (Shoimah, 2018, 172). Pembiasaan adalah salah satu metode pengajaran yang efektif. Misalnya, setiap hari senin siswa dibiasakan mengucapkan salam dan salim dengan guru piket yang berada didepan sekolah, shalat berjamaah, berdoa sebelum dan sesudah jam pelajaran terakhir, berbaris saat masuk kelas dan sebagainya.

b) Kegiatan Spontan 


\section{AL-ADABIYAH: Jurnal Pendidikan Agama Islam}

Kegiatan ini bersifat spontan atau respon cepat, pada waktu terjadi keberadaan tertentu. Misalnya, mengumpulkan sumbangan bagi korban bencana alam, mengunjungi teman yang sakit atau sedang tertimpa musibah, dan sebagainya.

c) Keteladanan

Kegiatan yang menimbulkan sikap dan perilaku peserta didik karena meniru perilaku atau sikap guru dan tenaga kependidikan di sekolah, bahkan perilaku seluruh warga sekolah yang dewasa lainnya sebagai model. Dalam hal ini akan dicontoh oleh siswa misalnya, kerapian baju para pengajar, kebiasaan warga sekolah untuk disiplin, tertib dan teratur, tidak pernah terlambat masuk sekolah, saling peduli dan kasih sayang, perilaku sopan santun, dan sebagainya.

d) Pengkondisian

Kegiatan yang menciptakan kondisi mendukung keterlaksanan pendidikan karakter, misalnya kondisi fasilitas sekolah yang rapi dan bersih, halaman sekolah yang hijau penuh pepohonan dan tidak ada putung rokok disekolah.

e) Pembudayaan

Kegiatan yang perlu adanya peran masyarakat sebagai kontrol sosial untuk mengingatkan seseorang ketika berada diluar lingkungan keluarga. Dengan begitu siswa akan merasa tidak nyaman ketika tidak mengikuti aturan yang ditetapkan masyarakat tersebut. Selain itu, hukuman juga diperlukan agar siswa yang melanggar aturan menjadi jera dan pelan-pelan merubah kebiasaan buruknya agar menciptakan lingkungan yang berkarakter.

\section{c. Konsep Tausiyah}

Membahas mengenai tausiyah tidak lepas dengan pembahasan dakwah, karena tausiyah merupakan istilah lain dari dakwah bi al-lisan yaitu dakwah yang dilakukan oleh lisan. Secara etimologi diartikan sebagai suatu proses penyampaian (tabligh) atas pesan-pesan tertentu, berupa ajakan atau seruan agar orang lain memenuhi ajakan tersebut (Amin, 2009, 2). Ada dua tujuan seseorang perlu menyeru ajaran islam yaitu tujuan khusus dan umum (Alimuddin, 2007, 75). Tujuan umum tausiyah adalah mewujudkan kebahagian dan kesejahteraan hidup di dunia maupun di akhirat. Sedangkan tujuan khususnya adalah bagi masyarakat, membina mental umat muslim untuk 


\section{AL-ADABIYAH: Jurnal Pendidikan Agama Islam}

beriman kepada allah. Bagi siswa, mendidik dan mengajarkan anak-anak agar tidak menyimpang dari fitrahNya, sehingga dapat meningkatkan iman dan ketaqwaannya sejak dini.

\section{d. Unsur-Unsur Tausiyah}

Dalam menyampaikan ajaran islam atau tausiyah terdapat beberapa unsur (Pimay, 2005, 6) sebagai berikut:

1. DAI (Subjek)

DAI adalah juru tausiyah atau lebih sering dikenal dengan komunikator dakwah yaitu orang yang harus menyampaikan pesan atau wasilah. Adapun tiga persyaratan yang harus dipahami untuk menjadi dai (Superfikr, 2012, 24-26) yaitu

a) Memiliki kepribadian Islam yang tangguh sehingga pola pikir dan pola sikapnya bisa diteladani oleh kaum muslimin.

b) Wawasan yang luas baik berkait dengan ajaran yang menjadi tema utama dalam dakwah maupun wawasan kekinian.

c) Kemampuan atau keterampilan (skill) dakwah harus menarik, enak didengar dan antusias masyarakat yang mendengarkan baik dilakukan dengan cara berkhutbah maupun ceramah.

2. Mad'u (Objek)

Mad'u adalah manusia yang menjadi sasaran atau manusia penerima tausiyah baik sebagai individu maupun kelompok, baik manusia yang beragama islam atau tidak. Adapun bentuk-bentuk mad'u yang digolongkan menjadi tiga sebagai berikut :

a) Crowd

Kelompok orang yang terkumpul pada suatu tempat atau ruangan tertentu yang terlibat dalam suatu persoalan atau kepentingan bersama secara tatap muka (direct communication). Dalam hal ini, keanggotaannya biasanya bersifat permanen atau temporal.

b) Publik

Kelompok abstrak dari orang-orang yang menaruh perhatian pada suatu persoalan atau kepentingan yang sama karena mereka terlibat dalam suatu pertukaran pemikiran melalui komunikasi tidak langsung untuk mencari penyelesaian atau kepuasan atas persoalan atau kepentingan mereka.

c) Massa 
Orang banyak yang sangat heterogen, tidak terikat oleh suatu tempat dan interaksinya sangat kurang, demikian masalah yang mereka hadapi masing-masing masih terpencar-pencar. Massa lebih luas dari publik, audiens atau crowd. (Ramlah, 2015, 70) Dengan adanya hal tersebut dai yang tidak memiliki pengetahuan yang cukup mengenai masyarakat akan mengalami kegagalan dalam tausiyah.

3. Maddah (materi)

Materi yang disampaikan meliputi seluruh ajaran islam dengan segala aspeknya dan hal ini dijiwai dengan keberadaan rasul Allah sebagai pembawa rahmat di alam ini. Materi yang disampaikan meliputi seluruh ajaran islam dengan segala aspek dan hal ini dijiwai dengan keberadaan Rasul Allah sebagai pembawa rahmat di alam ini. Namun secara garis besar materi tausiyah dapat diklasifikasikan menjadi tiga hal pokok (Anshari, 1993, 146) sebagai berikut :

1) Masalah aqidah, yaitu serangkaian ajaran yang menyangkut sistem keimanan/kepercayaan terhadap Allah swt. Dalam hal ini, bukan saja pembahasannya tertuju pada masalah-masalah yang wajib di-imani, akan tetapi materi dakwah meliputi masalah-masalah yang dilarang sebagai lawannya, misalnya syirik (menyekutukan adanya Tuhan), ingkar dengan adanya Tuhan dan sebagainya

2) Masalah syariah, yaitu serangkaian ajaran yang menyangkut aktifitas manusia muslim dalam semua aspek kehidupan, mana yang boleh dilakukan dan yang tidak boleh dilakukan. Dalam hal ini juga menyangkut hubungan manusia dengan Allah dan hubungan manusia dengan sesamanya.

3) Masalah akhlak, yaitu menyangkut tata cara berhubungan baik secara vertikal dengan Allah SWT, sedangkan secara horizontal yaitu tata cara berhubungan baik sesama manusia dan seluruh makhluk-Nya. (Aminuddin, 2002, 153) Akhlak secara garis besar dibedakan menjadi dua yaitu akhlak terpuji (akhlak yang dapat membawa nilai-nilai positif bagi masyarakat) dan akhlak tercela (akhlak yang berkaitan dengan hawa nafsu yang berada dalam lingkaran setan dan bersifat negatif).

4. Thariqah (Metode)

Metode adalah suatu cara yang ditempuh atau ditentukan secara jelas untuk mencapai dan menyelesaikan suatu tujuan. Metode yang 


\section{AL-ADABIYAH: Jurnal Pendidikan Agama Islam}

dilakukan untuk menyampaikan ajaran materi islam. Adapun metode tausiyah yang dapat dijadikan landasan dalam melaksanakan dakwah yaitu:

a) Metode bil hikmah

Metode yang sesuai untuk semua golongan, disampaikan dengan cara memperhatikan berbagai faktor yang mempengaruhi objek. Kriteria metode ini dilihat dari penyampaian dai yang baik dan isi yang sesuai.

b) Metode wal maw'izah al-hasanah

Metode berupa pemberian nasihat atau pengajaran yang baik. Nasihat tersebut disifati oleh al hasanah yaitu baik atau buruk. Kriteria metode ini dilihat dari nasehat yang baik dan orang yang menyampaikan dapat memberikan teladan.

c) Metode al-mujadalah bi allatiy hiya ahsan

Metode dengan jalan diskusi atau debat tetapi dengan cara yang baik.(Pirol, 2018, 54) Kriteria ini adalah menghindari sikap emosional dan merendahkan martabat mitra diskusi dengan mengedepankan argumentasi yang tidak dapat dibantah kebenarannya.

5. Wasilah (Media)

Segala sesuatu yang dapat digunakan sebagai alat untuk mencapai tujuan yang telah ditentukan. Pada zaman yang modern ini, media dapat menarik perhatian yang lebih terhadap mad'u sesuai dengan tuntutan zaman. Adapun bentuk-bentuk media yang bisa digunakan untuk tausiyah meliputi lisan, tulisan, lukisan maupun audio visual.

\section{e. Konsep Akhlak}

Secara bahasa akhlak berasal dari bahasa arab jama' dari bentuk mufradat "khuluq" yang berarti budi pekerti, tabiat, perangai atau tingkah laku (Habibah, 2005, 73), sedangkan secara istilah adalah pengetahuan yang menjelaskan buruk atau tidak, mengatur pergaulan manusia dan menentukan tujuan akhir dari usaha dan pekerjaannya.

Akhlak merupakan perilaku yang terlihat dengan jelas, baik dalam perkataan maupun perbuatan yang memotivasi oleh dorongan karena Allah, pedoman akhlak yang baik berasal dari Nabi Muhammad SAW, karena akhlak Nabi Muhammad saw dikatakan sebagai akhlak islam yaitu akhlak pada ajaran Allah dan Rasulullah. Akhlak islam merupakan amal perbuatan yang sifatnya terbuka sehingga menjadi indikator seseorang menjadi muslim baik atau buruk. 
Rasulullah diutus menyempurnakan akhlak manusia bertujuan untuk memperbaiki hubungan makhluq (manusia) dengan Khaliq (Allah) dan hubungan baik antara makhluq (manusia) dengan makhluq (manusia). Sebagaimana firman Allah SWT dalam surah Al-Qalam sebagai berikut

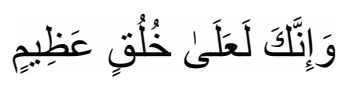

Artinya: "Dan sesungguhnya engkau ( Muhammad) benar-benar budi pekerti yang agung." (QS. A1-Qalam:4)

Dalam ayat ini menjelaskan bahwa Allah Swt telah menegaskan bahwa Nabi Muhammad Saw memiliki uswah al-hasanah (teladan yang baik). Hal ini menjadi syarat pokok bagi siapapun yang bertugas untuk memperbaiki akhlak orang lain kecuali dirinya sendiri sudah baik akhlaknya. Orang yang berpegang teguh pada Al-Quran dan melaksanakan dalam kehidupan sehari-hari, maka sudah termasuk meneladani akhlak Rasulullah. Orang yang memiliki akhlak terpuji akan memperoleh derajat yang tinggi di jannah Allah Swt sedangkan orang yang memiliki akhlak tercela akan terhalang dari kenikmatan Jannah.

Ada beberapa prinsip dasar islam yang berhubungan dengan falsafah akhlak (Munirah, 2017, 42-43) yaitu

a) Pentingnya akhlak dalam kehidupan

Akhlak menurut islam merupakan tingkatan setelah rukun iman dan ibadah sebagai implementasi bentuk perbuatan yang menentukan manusia baik atau buruk, dengan berprinsip bahwa apa yang kita lakukan berdasarkan perintah Allah dan berserah diri kepada-Nya. Tujuan islam menanamkan akhlak pada setiap manusia adalah menyiapkan manusia yang mampu menata kehidupan sejahtera dunia dan akhirat.

b) Akhlak islam merupakan kebiasaan yang tertanam dalam jiwa

Pembentukan sikap pribadi manusia terjadi melalui pengalaman kecil, pendidik atau Pembina pertama adalah orang tua kemudian guru dan dilanjutkan oleh tokoh masyarakat. Pembentukan akhlak yang baik adalah menjadi tanggung jawab ketiga peran tersebut. Faktor-faktor yang mempengaruhi pembentukan akhlak ada tiga bentuk yaitu (1) Aliran nativisme berpandangan bahwa manusia yang lahir telah memiliki potensi yang mempengaruhi hasil dari perkembangan selajutnya, karena faktor pembawaan dari diri siswa memiliki bentuk kecenderungan baik maka 


\section{AL-ADABIYAH: Jurnal Pendidikan Agama Islam}

melahirkan perbuatan menjadi baik. (2) aliran empiris berpandangan bahwa faktor yang paling berpengaruh dalam membentuk kepribadian siswa adalah lingkungan sosial termasuk pembinaan dan pendidikan yang diberikan karena dunia pendidikan menjadi sangat prioritas. (3) aliran konvergensi berpandangan bahwa pembentukan akhlak dipengaruhi oleh faktor internal dan eksternal, pembinaan yang dibuat khusus atau melalui metode lain. Karena manusia diciptakan telah membawa bakat tetapi untuk mengembangkannya perlu adanya pengaruh dari luar yakni dengan tuntunan dan bimbingan.

c) Akhlak karimah sesuai dengan fitrah

Akhlak memiliki nilai mutlak berupa sikap terpuji atau tercela yang berlaku kapan dan dimana saja didalam kehidupan sehari-hari, tidak dibatasi oleh ruang dan waktu. Manusia akan mendapatkan kebahagiaan yang hakiki apabila mengikuti nilai-nilai kebaikan sesuai Al-Quran dan Sunnah. Akhlak islam benar-benar memelihara eksistensi manusia sesuai dengan fitrahnya. Naluri manusia atau fitrah memiliki keterkaitan antara potensi yang dimiliki manusia dengan pengaruh eksternal dalam hal lingkungan. Menumbuhkan dan mengembangkan fitrah seseorang yang akan membentuk manusia yang beriman. Bertakwa dan berakhlak karimah.

\section{f. Dasar dan Tujuan Akhlak}

Tujuan akhlak adalah terbentuknya suatu sikap batin yang mendorong munculnya keutamaan jiwa yang biasa disebut al-Sa'adat al-Haqiqiyat (kebahagiaan yang hakiki). Akhlak merupakan pusat yang menjadi dasar penilaian keutamaan manusia karena dapat memberikan ketenangan batin sehingga tercapai tujuan hidup yang sebenarnya (Rizal, 2018, 78-79). Akhlak merupakan pusat yang menjadi dasar penilaian keutamaan manusia karena dapat memberikan ketenangan batin sehingga tercapai tujuan hidup yang sebenarnya. Al-Ghazali mendefinisikan tujuan pendidikan akhlak adalah proses manusia mendekatkan diri kepada Allah Swt sebagai tujuan akhir yang akan dicapai oleh manusia, membersihkan diri dengan terbiasa selalu mendekatkan diri kepad Allah Swt sehingga mendapatkan ketenangan dunia dan akhirat.

Pendidikan akhlak adalah suatu upaya pembentukan manusia untuk menjadi lebih sempurna. Menurut Al-Ghazali manusia dapat mencapai 


\section{AL-ADABIYAH: Jurnal Pendidikan Agama Islam}

kesuksesan apabila diiringi dengan usaha mencari ilmu kemudian mengamalkan fadillah. Membentuk akhlak siswa dapat dilatih untuk selalu mendekatkan diri kepada Allah Swt agar tidak muncul sifat-sifat buruk dalam hati. Penyucian jiwa dan dekat kepada Allah merupakan cara menghilangkan penyakit jiwa, jika cara tersebut dilakukan maka dapat mencapai tujuan pendidikan yang lain yaitu menanamkan akhlak yang terpuji dalam diri siswa.

\section{g. Bentuk-bentuk akhlak}

a) Akhlak terhadap Allah SWT

Akhlak yang baik kepada Allah berucap dan bertingkah laku yang terpuji baik melalui ibadah langsung kepada Allah maupun melalui perilaku tertentu yang mencerminkan hubungan atau komunikasi dengan Allah diluar ibadah lain (Habibah, 2015, 78-86). Allah Swt telah mengatur hidup manusia dengan adanya hukum perintah dan larangan, hal ini untuk menegakkan keteraturan dan kelancaran hidup manusia. Berikut ini beberapa akhlak terhadap Allah Swt:

1) Beriman yaitu meyakini wujud dan keesaan Allah serta meyakini apa yang difirmankan-Nya seperti beriman kepada Allah Swt. Beriman merupakan pondasi dari seluruh bangunan akhlak islam.

2) Taat yaitu patuh segala perintah-Nya dan menjauhi segala larangan-Nya. Sikap taat kepada perintah Allah merupakan sikap yang mendasar setelah beriman, ia merupakan gambaran langsung dari adanya iman didalam hati.

3) Ikhlas yaitu melaksanakan perintah Allah dengan pasrah tanpa mengharapkan sesuatu kecuali ridha Allah. Oleh karena itu, dalam melaksanakannya harus menjaga akhlak sebagai bukti keikhlasan menerima hukum-hukum tersebut.

4) Tawakal yaitu menyerahkan diri kepada Allah dalam melaksanakan suatu rencana. Sikap tawakal merupakan gambaran dari sabar dan menggambarkan kerja keras dan sungguh-sungguh dalam melaksanakan suatu rencana.

5) Syukur yaitu mengungkapkan rasa syukur kepada Allah atas nikmat yang telah diberikan-Nya, ungkapan syukur bisa berupa kalimat atau perilaku. 
6) Sabar yaitu ketahanan mental dalam menghadapi kenyataan yang menimpa seseorang, sabar tidak akan mengenal putus asa dalam menjalankan ibadah kepada Allah Swt.

7) Husnudzan yaitu berprasangka baik terhadap Allah Swt merupakan gambaran harapan dan kedekatan seseorang kepada-Nya sehingga apa saja yang diterimanya dipandang sebagai suatu yang terbaik bagi dirinya.

8) Doa yaitu meminta kepada Allah apa saja yang diinginkan dengan cara yang baik sebagaimana yang dicontohkan oleh Rasulullah, doa merupakan cara membuktikan kelemahan manusia dihadapan Allah dan merasa mampu dengan usahanya sendiri.

b) Akhlak Terhadap Rasulullah Saw.

Berakhlak kepada rasulullah dapat diartikan suatu sikap yang harus dilakukan manusia kepada Rasulullah Saw sebagai rasa terimakasih atas perjuangannya membawa manusia ke jalan yang benar. Berakhlak kepada Rasulullah perlu kita lakukan atas dasar bahwa jasa dalam menyelamatkan manusia dari kehancuran, berjasa dalam membina akhlak yang mulia dengan cara memberikan contoh teladan yang baik kepada umat manusia, dan berjasa dalam menjelaskan Al-Quran kepada manusia sehingga jelas dan mudah dilaksanakan. Adapun cara berakhlak kepada Rasulullah Saw. sebagai berikut:

1) Ridha dan beriman kepada Rasulullah Saw.

2) Menaati dan mengikuti kepada Rasulullah Saw.

3) Mencintai dan memuliakan Rasulullah Saw.

4) Mengucapkan shalawat dan salam kepada Rasulullah Saw.

5) Melanjutkan misi Rasulullah menegakkan nilai-nilai islam dan menyebarluaskannya.

c) Akhlak Terhadap Diri Sendiri

Islam mengajarkan manusia menjaga diri baik jasmani maupun rohani agar memelihara dan menjaga akal manusia dari pikiran kotor, selain itu mensucikan jiwa agar menjadi orang yang beruntung. Adapun akhlak terhadap diri sendiri antara lain:

1) Amanah yaitu sikap pribadi yang setia, tulus hati dalam melaksanakan sesuatu yang dipercayakan kepadanya.

2) Shadiq yaitu benar dan jujur baik dalam perkataan maupun perbuatan. 
3) Adil yaitu menempatkan sesuatu pada tempatnya.

4) Keberanian yaitu sikap mental yang menguasai hawa nafsu dan berbuat semestinya.

5) Kekuatan yaitu kekuatan fisik, jiwa yang semangat, dan kecerdasan.

6) Kesabaran yaitu sabar ketika ditimpa musibah dan dalam mengerjakan sesuatu.

7) Kasih sayang yaitu sifat mengasihi terhadap diri sendiri, orang lain dan sesama makhluk.

d) Akhlak Terhadap Masyarakat

Akhlak tidak lepas dari pendidikan sosial yang timbul didalam masyarakat karena selalu tumbuh dan berkembang sesuai dengan kemajuan perkembangan masyarakat. Adapun akhlak terhadap masyarakat sebagai berikut:

1) Memuliakan tamu

2) Menghormati nilai dan norma yang berlaku dalam masyarakat

3) Saling menolong dalam melakukan kebajikan takwa

4) Menganjurkan anggota masyarakat berbuat baik dan mencegah perbuatan jahat

5) Bermusyawarah dalam segala urusan kepentingan bersama.

6) Menunaikan amanah yang telah diberikan oleh masyarakat kepada kita.

e) Akhlak Terhadap Keluarga

Keluarga merupakan peran utama bagi pendidikan pertama bagi anak, maka perlu adanya akhlak terpuji bagi orang. Karena ibu yang telah berjuang mengandung sampai melahirkan dan ayah yang memberikan nafkah tanpa ada batas waktu. Oleh karena itu, perlu adanya akhlak baik untuk orang tua yaitu:

1) Mencintai mereka melebihi rasa cinta ini kita terhadap kerabat yang lain.

2) Lemah lembut dalam perkataan dan perbuatan.

3) Merendahkan diri di hadapannya.

4) Berdoa kepada mereka dan meminta doa kepada mereka.

\section{Hasil dan Diskusi}

1. Internalisasi Nilai-Nilai Karakter Religius Melalui Program Tausiyah Akhlak pada siswa kelas VII di SMP Al-Furqan Jember 


\section{AL-ADABIYAH: Jurnal Pendidikan Agama Islam}

Karakter religius sangat penting untuk menjadikan anak merasa bahwa Allah selalu melihat dan mengawasi setiap tingkah lakunya, sehingga dengan pembiasaan secara bertahap mampu membentuk karakter terpuji dan mengamalkannya dalam kehidupan sehari-hari. Berbagai macam kegiatan yang bisa digunakan untuk membentuk karakter religius anak, salah satunya melalui program tausiyah akhlak.

Dibentuknya program tausiyah akhlak ini adalah proses pembinaan kepada siswa diluar materi untuk membentuk karakter, siswa yang mengerti dasar hukum adanya suatu sebab, maka akan ada tindakan spontan dari diri individu dan dapat memperbaiki akhlak siswa menjadi manusia yang bertakwa kepada Allah SWT dan manusia yang mulia dalam ajaran agama islam, sehingga nantinya sesuai dengan visi dan misi sekolah yaitu mewujudkan siswa yang berkarakter, bermutu dan berdaya saing tinggi.

Berdasarkan hasil wawancara diatas dapat diketahui penanaman nilai-nilai karakter religius melalui tausiyah akhlak dan diimbangi dengan pembiasaan yang dilakukan disekolah agar nantinya dapat tertanam dalam diri siswa karena siswa SMP merupakan remaja yang sangat rentan dan labil terhadap pengaruh dari lingkungan agar mereka bisa mengetahui mana yang baik dan buruk. Hal ini diperkuat dengan hasil observasi dari youtube bahwa siswa mengikuti acara tausiyah akhlak tersebut dengan tertib dan mendengarkan dengan seksama apa yang disampaikan oleh pemateri dari luar maupun guru bahkan ada siswa yang mencatat apa yang disampaikan oleh pemateri sebagai pembelajaran. Contohnya, sebelum masuk sekolah siswa seluruhnya melaksanakan shalat dhuha dan telah menjadi pembiasaan disekolah.

Pembahasan temuan kali ini peneliti menekankan tentang internalisasi nilainilai karakter religius melalui program tausiyah akhlak. Berdasarkan hasil penelitian bahwa program tausiyah akhlak ini dapat menjadikan perbaikan diri individu agar menjadi manusia berakhlak dan bertakwa kepada Allah, menjadikan manusia yang mulia sesuai dengan ajaran agama islam dan menanamkan keimanan siswa menjadi lebih kuat.

Hasil terkait diatas jika dibandingkan dengan teori yang ada terdapat kesamaan, diantaranya: 


\section{AL-ADABIYAH: Jurnal Pendidikan Agama Islam}

"Nabi Muhammad SAW diutus untuk membawa risalah utama yaitu untuk memperbaiki akhlak manusia yang bersumber dari Al- Quran dan hadis sesuai dengan teladan akhlak Nabi Muhammad SAW. Akhlak yang baik dan mulia akan mengantarkan kedudukan seseorang pada posisi yang terhormat dan tinggi. (Masy'ari, 1990: 10) Oleh karena itu, setiap tingkah laku dan perbuatan sehari-hari sesuai dengan teladan Nabi Muhammad SAW."

Dari analisa tersebut peneliti dapat menyimpulkan bahwa internalisasi nilainilai karakter religius bisa meliputi pemberian pemahaman, nasehat, pembiasaan, pembinaan dan keteladanan. Menanamkan keimanan membutuhkan waktu yang panjang dan dilakukan secara terus menerus, agar siswa tersebut dapat memperbaiki akhlak agar menjadi manusia yang bertakwa kepada Allah SWT dan akan mengantarkannya kepada kedudukan yang tertinggi dan terhormat.

Terlaksananya program ini diimbangi oleh adanya pembiasaan kegiatan disekolah untuk menunjang siswa agar memiliki wawasan agama yang luas sehingga nantinya menjadi pondasi yang kuat sebagai pedomana hidup siswa. tausiyah yang disampaikan pemateri dari luar juga menyampaikan bagaimana akhlak Nabi Muhammad SAW yang harus diteladani oleh siswa, karena akhlak rasulullah disebut akhlak islam yang bersumber pada Al-Quran dan hadist.

Sekolah membentuk kegiatan kultum yang harus diikuti oleh seluruh siswa, karena guru ingin mengetahui seberapa besar siswa dapat memahami pesan yang disampaikan pada saat tausiyah akhlak tersebut. Dari program tersebut dapat memberikan pengalaman untuk siswa sehingga siswa lebih memahami.

\section{Internalisasi Nilai-Nilai Karakter Disiplin Melalui Program Tausiyah Akhlak pada siswa kelas VII di SMP Al-Furqan Jember}

Pendidikan karakter yang harus dikembangkan dalam dunia pendidikan salah satunya adalah karakter disiplin. Karakter disiplin merupakan menaati aturan yang telah dibuat oleh pendidikan untuk mencapai tujuan yang telah ditentukan, kedisiplinan sangat penting bagi siswa bukan hanya kebijakan atau aturan yang harus ditaati melainkan kesadaran sendiri untuk meningkatkan keberhasilan yang tinggi, kedisiplinan yang terbentuk dengan kesadaran sendiri akan membentuk pribadi yang kuat, tangguh dan bertanggung jawab terhadap kemajuan diri dan tugas yang diterimanya. Dengan karakter disiplin dapat mengendalikan sikap buruk siswa yang muncul dalam dirinya dan membangkitkan semangaat siswa untuk terus melakukan kebaikan. 


\section{AL-ADABIYAH: Jurnal Pendidikan Agama Islam}

Berdasarkan hasil wawancara dapat diketahui bahwa melalui program tausiyah akhlak dapat membangkitkan semangat siswa karena pemateri menyampaikan metode yang menyenangkan sehingga mudah dipahami dan dimengerti oleh siswa. Pengaplikasian program tausiyah tersebut sekolah membuat kegiatan kultum yang diikuti oleh seluruh siswa. Hal ini diperkuat dengan hasil observasi yang dilakukan melalui media sosial bahwa kegiatan tausiyah akhlak dapat membentuk karakter disiplin yang diimbangi dengan pembiasaan setiap hari contohnya, sebelum masuk sekolah siswa berbaris dengan tertib didepan gerbang untuk bersalaman dengan guru, perwakilan OSIS dan duta karakter.

Sekolah membentuk kegiatan kultum bertujuan untuk mengetahui seberapa besar kemampuan siswa untuk menyampaikan pesan yang didapatkan melalui program tausiyah akhlak, karena dengan kegiatan tersebut akan membuat siswa untuk melaksanakan hal kebaikan dan biasanya tema yang disampaikan pada saat kultum termotivasi dari program tausiyah akhlak tersebut. Hasil temuan diatas jika dibandingkan dengan teori yang ada terdapat kesamaan (Fitri, 2014: 26), diantaranya:

"Landasan karakter berkaitan dengan berkaitan dengan kecakapan untuk menggunakan keadaan lingkungan sebagai alat untuk mencapai tujuan. Oleh sebab itu, untuk membentuk siswa yang berkarakter dapat dilakukan dengan memberikan pengalaman".

Setelah siswa mampu menyampaikan pesan kepada seluruh siswa akan memunculkan karakter lainnya seperti mengasah rasa percaya diri dan melatih mental siswa untuk tampil didepan teman-temannya, menyampaikan kultum belajar dengan penuh tanggung jawab dan mandiri karena siswa belajar secara otodidak melalui media sosial maupun dari program tausiyah akhlak tersebut. Dari seluruh kegiatan tersebut, diharapkan siswa dapat memiliki sikap akhlakul karimah didalam dirinya dan melaksanakan segala sesuatu dengan penuh rasa tanggung jawab. Hasil temuan diatas jika dibandingkan dengan teori yang ada terdapat kesamaan (Narwanti, 2014: 6) diantaranya:

"Pendidikan karakter bertujuan untuk membentuk dan membangun pola pikir, sikap, dan perilaku peserta didik agar menjadi pribadi yang positif, berakhlak karimah, berjiwa luhur dan bertanggung jawab". 


\section{AL-ADABIYAH: Jurnal Pendidikan Agama Islam}

Dari hasil temuan tersebut peneliti dapat menyimpulkan bahwa untuk membentuk karakter disiplin sangatlah penting bagi siswa, karena dengan adanya menanamkan kedisiplinan akan memunculkan karakter baru tetapi bukan hanya memberikan siswa materi saja tetapi perlu diimbangi kebiasaan-kebiasaan sehingga akan membentuk pengalaman siswa dan respon cepat berupa tindakan siswa. berbagai macam kegiatan untuk membentuk karakter siswa, salah satunya melalui kultum. pembiasaan kultum membangun pola pikir peserta didik menjadi pribadi positif dan akan menumbuhkan sikap bertanggung jawab.

\section{Kesimpulan}

Pertama, internalisasi nilai-nilai karakter religius melalui program tausiyah akhlak yang dilaksanakan pada setiap hari jum'at, diikuti oleh seluruh siswa dengan pemateri dari luar dan guru internal. Program ini terbentuk untuk menjadikan perbaikan diri individu agar menjadi manusia berakhlak dan bertakwa kepada Allah, menanamkan keimanan siswa menjadi lebih kuat sesuai dengan visi dan misi sekolah yaitu mewujudkan siswa yang berkarakter, bermutu dan berdaya saing. Kedua, internalisasi nilai-nilai karakter disiplin melalui program tausiyah akhlak dapat mengendalikan perilaku buruk yang muncul pada diri siswa dan membangkitkan semangaat siswa untuk melakukan kebaikan dengan penuh tanggung jawab, melaksanakan segala sesuatunya dengan tepat waktu dan menumbuhkan percaya diri dari pembiasaan-pembiasaan yang dilakukan oleh sekolah.

\section{Referensi}

Aminuddin. 2002. Pendidikan Agama Islam Untuk Perguruan Tinggi. Bogor:Ghala Indonesia

Anshari, M. Hafi. 1993. Pemahaman dan Pengamalan Dakwah. Surabaya:Al-Ikhlas Ibrahim. 2015. Metodologi Penelitian Kualitatif. Pontianak: Alfabeta 


\section{AL-ADABIYAH: Jurnal Pendidikan Agama Islam}

Masyari, Anwar. 1990. Akhlak Al-Qur'an. Surabaya: PT. Bina Ilmu

Munir Amin, Samsul. 2009. Ilmu Dakwah. Jakarta:Amzah

Munirah. 2017. Akhlak Dalam Perspektif Pendidikan Islam. AULADUNA. 4(2):42-43

Narwanti, Sri. 2014. Pendidikan Karakter. Yogyakarta: Familia

Nurwahidah, alimuddin. 2007. Konsep Dakwah Dalam Islam. Hunafa. (01):75

Pimay, Awaluddin . 2005. Pendidikan Dakwah. Semarang: Rasail

Pirol, Abdul. 2018. Komunikasi dan Dakwah Islam. Yogyakarta:Deepublish

Ramlah. 2015. Meretas Dakwah di Kota Palopo. Yogyakarta:Deepublish

Samani, Muchlas. 2011. Konsep dan Model Pendidikan Karakter. Bandung: PT. Rosdakarya Remaja

Sekretaris Negara RI, Undang-Undang Nomor 20 Tahun 2003 Tentang Sistem Pendidikan BAB II Pasal 3

Superfikr. 2012. Islamic Public Speaking A Powerful Secret For Powerful Muslim Public Speaker. Solo:Tinta Media

Syamsul, Rizal. 2018. Akhlak Islami Perspektif Ulama Salaf. Jurnal Pendidikan Islam. $7(1): 78$

Syarifah, Habibah. 2015. Akhlak dan Etika Dalam Islam. Jurnal Pesona Dasar. 1(4): 73 